\title{
Nematode-Induced Changes of Transporter Gene Expression in Arabidopsis Roots
}

\author{
Ulrich Z. Hammes, ${ }^{1}$ Daniel P. Schachtman, ${ }^{1}$ R. Howard Berg, ${ }^{1}$ Erik Nielsen, ${ }^{1}$ Wolfgang Koch, ${ }^{2}$ \\ Lauren M. McIntyre, ${ }^{3}$ and Christopher G. Taylor ${ }^{1}$ \\ ${ }^{1}$ Donald Danforth Plant Science Center, 975 N. Warson Rd., St. Louis, MO 63132, U.S.A.; ${ }^{2}$ Plant Physiology, ZMBP, \\ University of Tübingen, Auf der Morgenstelle 1, 72076 Tübingen, Germany; ${ }^{3}$ Purdue University Computational Genomics, \\ Department of Agronomy, West Lafayette, IN 47907, U.S.A.
}

Submitted 2 June 2005. Accepted 11 July 2005.

\begin{abstract}
Root-knot plant-parasitic nematodes (Meloidogyne spp.) account for much of the damage inflicted to plants by nematodes. The feeding sites of these nematodes consist of "giant" cells, which have characteristics of transfer cells found in other parts of plants. Increased transport activity across the plasma membrane is a hallmark of transfer cells, and giant cells provide nutrition for nematodes; therefore, we initiated a study to identify the transport processes that contribute to the development and function of nematode-induced feeding sites. The study was conducted over a 4-week period, during which time the large changes in the development of giant cells were documented. The Arabidopsis ATH1 GeneChip was used to identify the many transporter genes that were regulated by nematode infestation. Expression of 50 transporter genes from 18 different gene families was significantly changed upon nematode infestation. Sixteen transporter genes were studied in more detail using real-time reverse-transcriptase polymerase chain reaction to determine transcript abundance in nematode-induced galls that contain giant cells and uninfested regions of the root. Certain genes were expressed primarily in galls whereas others were expressed primarily in the uninfested regions of the root, and a third group was expressed evenly throughout the root. Multiple transport processes are regulated and these may play important roles in nematode feeding-site establishment and maintenance.
\end{abstract}

Additional keywords: membrane transport, microarray.

Plant-parasitic nematodes are among the most destructive plant pathogens. Root-knot nematodes (Meloidogyne spp.) are capable of reproducing on over 2,000 species of plants and are responsible for approximately half of the overall nematode damage in crops (Sasser 1980). The interaction between the root and the nematode begins when an infective second-stage juvenile (J2) locates and penetrates a root behind the root cap in the zone of elongation or at rupture sites of lateral roots (Krusberg and Nielsen 1958). Upon entering the root, the J2 migrates towards the stele, where it establishes a feeding site. It is hypothesized that substances initially produced in the dor-

Corresponding author: Daniel P. Schachtman; Telephone: 1-314-5871421; Fax: 1-314-587-1521; E-mail: dschachtman@danforthcenter.org

* The $\boldsymbol{e}$-Xtra logo stands for "electronic extra" and indicates the HTML abstract available on-line contains a supplemental table not included in the print edition, which provides data gathered from the analysis of the transporter genes found on the ATH1 GeneChip. sal and subventral pharyngeal glands of the nematode are injected into the plant cells that surround the head of the nematode to initiate the feeding site (Hussey 1989).

Symptoms of plant infestation by root-knot nematodes include knot- or gall-like formations on the roots. These knots, or galls, inhibit the ability of the root to take up nutrients and water (Dorhout et al. 1991). Knot formation is due in large part to the development of specialized feeding cells called "giant cells". Normally, four to eight root cells undergo a morphogenesis into a feeding structure consisting of several giant, multinucleated cells that are similar to transfer cells in that they have a cell wall labyrinth with extensions into the cytoplasm (Bird 1961; Jones and Northcote 1972; Offler et al. 2003). Characteristics of giant cells also include large numbers of mitochondria and plastids, numerous small vacuoles, and dense cytoplasm (Bird 1961; Hussey and Mims 1991; Jones and Dropkin 1976). Giant cells are metabolically very active. High levels of total protein, amino acids, glucose, glucose 6phosphate, and ATP are found in root-knot nematode-induced giant cells (Gommers and Dropkin 1977). The increased metabolic activity of giant cells stimulates the mobilization of photosynthates from the shoot to the giant cells, where the nematode can easily access and withdraw the transferred assimilates (Bird and Loveys 1975; McClure 1977).

One of the defining features of root-knot nematode-induced giant cells that suggest they function as transfer cells is the presence of cell wall ingrowths. In marked contrast to the increase in surface area, the frequency of plasmodesmata decreases, particularly in areas of cell wall ingrowths (Huang and Maggenti 1969; Jones 1980). Due to the lack of plasmodesmata, it has been concluded that the bulk of solutes enter giant cells across the plasma membrane via apoplastic transport. The relative symplastic isolation of nematode feeding cells has been observed in several plant-parasitic nematode systems (Böckenhoff et al. 1996; Dorhout et al. 1993; Jones 1980). Therefore, it is likely that specialized membrane transport proteins are deployed to regulate the flow of nutrients into and out of giant cells, as has been demonstrated for transfer cells. A recent study on symplastic trafficking in Heterodera schachtiiinfested Arabidopsis roots showed that syncytial cells are not symplastically isolated (Hoth et al. 2005). Studies using these tools have not yet been reported using Meloidogyne incognita; therefore, giant cells may be confirmed to be symplastically isolated. In classical plant transfer cells, transporters for sucrose, amino acids, and H+-ATPases have been localized to the plasma membrane of these cells and are thought to control nutrient flow into the developing seed (Harrington et al. 1997; Tegeder et al. 2000; Wang et al. 1995). To date, only a few genes that 
encode membrane transport proteins have been demonstrated to be upregulated (Gheysen and Fenoll 2002) upon nematode infestation. These genes include the aquaporin TobRB7 (Opperman et al. 1994), a sucrose transporter (Juergensen et al. 2003), and an $\mathrm{H}^{+}$-ATPase (Bird and Wilson 1994).

Evidence suggesting an important role for transport proteins in nematode feeding sites led us to conduct a global analysis of the regulation of transporter gene expression after nematode infection. We used a whole-genome Affymetrix ATH1 GeneChip to compare roots from control and from root-knot nematode $(M$. incognita)-infested plants. We focused our hypotheses testing for differential gene expression on only those features encoding membrane transport proteins. This allowed us to identify transporter genes whose expression changed due to nematode infestation. Additional studies using real-time polymerase chain reaction (PCR) methods and promoter:: $\beta$-glucuronidase (GUS) constructs allowed for the tissue localization of selected genes.

\section{RESULTS}

\section{Characterization of knot and giant-cell development.}

During feeding site formation, plant cells undergo dramatic changes in size and morphology, and these changes are accompanied by concomitant rearrangements of subcellular organelles. This phenomenon has been described for several plant species. Although the infection process of Arabidopsis by root-knot nematodes has been described previously (Sijmons et al. 1991), detailed studies focusing on the ultrastructure of giant cells throughout their development have not been reported for Arabidopsis. Altered expression of membrane transport proteins occurs in the context of these cellular changes; therefore, we undertook a detailed examination of the ultrastructural changes that occur during development of root knots and giant cells in Arabidopsis roots. Based on these studies, we selected three timepoints representing early (1 week postinoculation), intermediate ( 2 weeks postinoculation), and late (4 weeks postinoculation) stages during knot and giant-cell development.

Because the penetration of the roots by nematodes was not synchronous, we selected electron microscopic images that were representative of development at each timepoint (Fig. 1). At the 1-week stage, developing giant cells generally were characterized by the presence of multiple nuclei displaying lobed morphologies (not shown), and large numbers of vacuolar structures were visible (Fig. 1A; arrows). No significant cell wall thickening or plasma membrane proliferation was observed in these early-stage giant cells. Many of the intermediate-stage giant cells already were expanded significantly. This expansion was accompanied by and perhaps driven by the development of large central vacuole compartments (Fig. 1B; asterisk) and numerous smaller vacuolar structures (Fig. 1B; arrows). This large central vacuolar structure was seen consistently in sections that contained giant cells at an intermediate stage of development. In addition to changes in the vacuolar membranes, complexes of Golgi and other organelles were found in increased numbers around the periphery of the cell. Many giant cells possessed thickened cell walls; however, no cell wall invaginations were visible at this intermediate stage (Fig. 1B). By week 4, most giant cells were fully developed and clearly were much larger than surrounding cells (Fig. 1C). Strikingly, despite the increased cell size of fully developed giant cells, large central vacuoles were absent, with the majority of the cell volume filled with cytoplasm and numerous smaller vacuolar structures. At this stage in development, the cell wall invaginations were evident in the fully developed giant cells, indicating a concomitant proliferation of plasma mem- brane (Fig. 1C). In addition, we often observed nematode feeding tubes in these cells, indicating that these cells were active nematode feeding sites. By week 4 , the nematodes were sedentary and unable to move, at which stage the gall and its specialized giant cells provide the nutrients required by the nematode to complete its life cycle.

\section{Differential expression of genes on the array.}

As the giant cell developed, we monitored the expression of transporter genes using the Affymetrix ATH1 GeneChip. Of the 867 transport proteins represented in the Arabidopsis Membrane Protein Library (AMPL) database (Ward 2001), 805 were on the array and 635 were classified as "present" in at least one replicate. Based on annotation, we found that one of these was not a transporter and therefore was excluded from further consideration. Of the 634 membrane proteins examined, 50 were found to be differentially expressed $(P<0.016$; false discovery rate $(\mathrm{FDR})=0.2$ ) in the comparison of the nematode-infested roots versus control (Table 1). The pattern of gene expression showed that there were no transporters with significant differences that were downregulated in week 1 and then upregulated in later weeks. Twenty of the genes were downregulated in all three time periods. Of the remaining 30, 26 were upregulated for both week 1 and week 2 and 16 were upregulated for all three timepoints.

In the 50 genes that showed significantly altered expression, six members of the peptide transporter/proton-coupled oligopeptide transporter family were downregulated at all timepoints and only 2 members of this family were upregulated, indicating an overall downregulation of peptide transport capacity in roots infested with root-knot nematode (Table 1). In contrast to the peptide transporters, three members of the auxin amino acid permease (AAAP) family were upregulated across the timepoints, whereas only one member of this family was downregulated at week 4 .

In addition to amino acid transporters, it appears that transcript levels of several genes encoding calcium transporters also changed in the nematode-infested roots (Table 1). Two P-type ATPase genes (Bonza et al. 2000; Geisler et al. 2000), AtACA8 $(P=0.001)$ and AtACA4 $(P=0.016)$, and a single gene encoding a CAX exchanger, AtCAX3 $(P=0.00006)$, were significantly different between nematode-infested roots and control roots and were upregulated at either week 1 or week 2 or at both timepoints (Table 1). Although, as yet, no clear functional role can be ascribed to the members of the multidrug/oligosaccharidyl-lipid/polysaccharide flippase (MOP) superfamily of transporters (Hvorup et al. 2003), we found that three generally were upregulated and two were downregulated (Table 1).

The giant cells act as sinks for photosynthates that are used by the nematodes as a carbon source. Because sucrose is the main nonreducing sugar transported to sink tissues, we expected to find that the expression of at least one sucrose transporter gene was induced. This was the case for AtSUC1, which was altered $(P=0.008)$ and upregulated at all three timepoints.

A number of inorganic ion transporters generally were downregulated upon nematode infestation, including members of the zinc iron permease (ZIP), voltage-gated ion channel (VIC), and ammonium transporter (AMT) families (Table 1) (Guerinot 2000; Mäser et al. 2001; Sohlenkamp et al. 2000).

\section{Verification of microarray data.}

To confirm that mRNA of features identified by microarray analysis were indeed differentially expressed, the degree of change of 16 genes was tested using quantitative real-time reverse-transcriptase polymerase chain reaction (RT-PCR) (iCycler; BioRAD, Hercules, CA, U.S.A.) by examining the control and infested tissue for each of the three timepoints. 
The 16 genes were chosen to represent members of the AAAP, major facilitator super family, plasma membrane intrinsic protein (PIP), and P-type ATPase families. The raw fold changes observed on the array ranged from 0.7 to 8 . The fold increase in response to nematode infestation measured by real-time RTPCR as a function of the fold change measured by microarray analysis is shown in Figure 2. The real-time RT-PCR analysis was in good agreement with the results derived from array analysis (Fig. 2): week $1, r^{2}=0.62(P=0.0004)$; week $2, r^{2}=$ $0.78(P<0.0001)$; and week $4, r^{2}=0.62 ;(P<0.0001)$. The qualitative change (up- or downregulated) measured in the microarray experiment were confirmed by quantitative PCR in all cases tested. This is consistent with several studies that used real-time PCR to verify microarray data and found good correlation between the two methods (Kääb et al. 2004; Paul et al. 2004; Wang et al. 2003).

\section{Tissue specificity of transporter gene expression.}

Because the GeneChip experiments were completed with RNA extracted from whole roots infested with nematodes, real-time RT-PCR experiments were carried out to determine whether selected genes were specifically expressed in regions where knots are present or were upregulated throughout infested roots. To address this question, galls from Arabidopsis plants representing an additional independent biological replicate were manually excised from the root tissue. Tissue from the week-2 timepoint was chosen because knots were readily excised from the surrounding tissue, and some genes upregulated at week 1 and week 4 also were induced at week 2. Genes for this analysis were chosen based upon either of two criteria. The first criterion was significance in the initial microarray study and relevance to transfer cell function. From this, we selected AtSUC1, AtACA8, AtAUX4/LAX3 (At2g21050), AtPIP2.6, AtAAP1, AtAUX1, AtMRP4, and AtANT1 for our detailed analysis (Fig. 3). The second criterion was previous evidence about amino acid transport processes in transfer cells (Tegeder et al. 2000) and evidence for water channel and amino acid transporter gene expression in giant cells after plant nematode infection (Opperman et al. 1994; Puthoff et al. 2003). Using this criterion, we selected members of the AAP family (AtAAP6, AtAAP3, and AtAAP7), the ANT family (At2g41190 and At1g80510), the LHT family (AtLHT4), and the putative aquaporin AtPIP 2.5 (Fig. 3). We also found that, by further analysis of supplemental data that was not annotated in a previous, smallerscale microarray experiment (8K GeneChip), AtPIP2.5 and

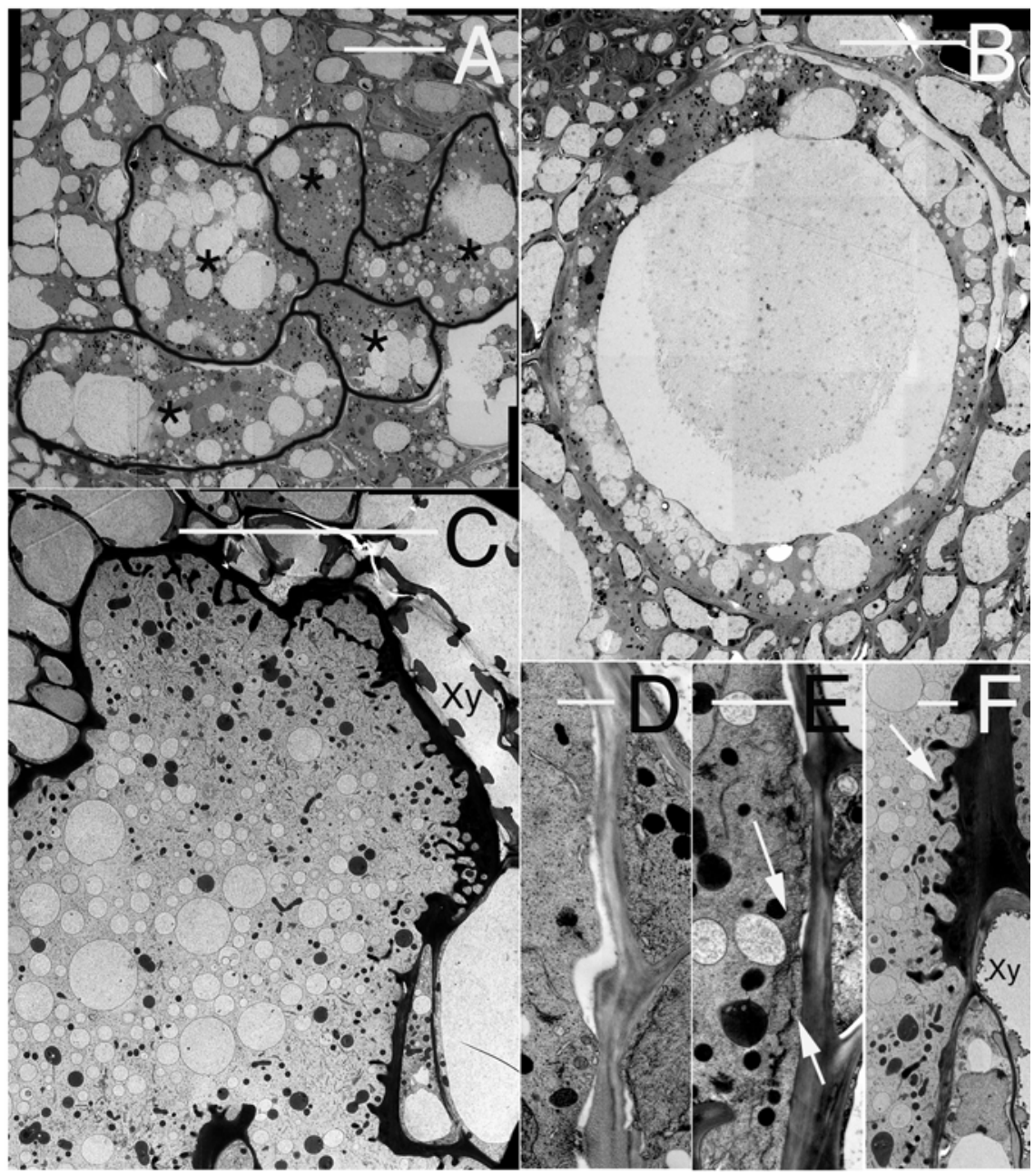

Fig. 1. Ultrastructure of freeze-substituted giant cells $\mathbf{A}$ and $\mathbf{D}, 1$ week, $\mathbf{B}$ and $\mathbf{E}, 2$ weeks, and $\mathbf{C}$ and $\mathbf{F}, 4$ weeks after infestation of Arabidopsis roots with nematodes. Bars $=20 \mu \mathrm{m}(\mathrm{A}-\mathrm{C})$ and $3 \mu \mathrm{m}(\mathrm{D}-\mathrm{F})$. A, Formation of the feeding site was observable within 1 week after infestation. Developing giant cells (asterisks, outlined in black) contain a number of vacuoles of sizes similar to vacuoles in adjacent, nongiant cells. Many of the vacuoles were found to be in clusters with some vacuoles showing signs of fusion. B, Second week of infestation, giant cells have unusually large vacuoles in addition to numerous smaller vacuoles (the vacuole in this cell is $60 \mu \mathrm{m}$ in diameter). C, After 4 weeks of infestation, giant cells have lost the large vacuole and are cytoplasm rich, with a large numbers of small vacuoles (Xy, xylem element). D through $\mathbf{F}$, Changes in walls of giant cells during development; in each micrograph, the giant cell is on the left side of the cell wall. At 1 week (C), the wall is relatively unchanged from that of nongiant cells. By the second week (E), a complex of ER and Golgi stacks is associated with the wall (arrows). Within 4 weeks (F), a transfer cell wall labyrinth develops (arrow), (Xy, xylem element). 
AtAAP6 were upregulated during beet cyst nematode infestation of Arabidopsis roots (Puthoff et al. 2003 supplemental data).

The transcript levels of 15 selected genes were studied in galls compared with uninfected sections of root using quantitative real-time RT-PCR (Fig. 3). With the exception of AtANT1 and $A t A A P 7$, all the genes chosen for this analysis were upregulated at the week-2 timepoint (in both array and RT-PCR). These two were downregulated in both week 1 and week 2 .

The detailed real-time PCR analysis of the 15 selected genes showed that they could be classified into three distinct groups. Group I included AtPIP2.5, AtAAP7, AtSUC1, AtACA8, AtAAP6, AtAAP3, and AtAUX4/LAX3, which were expressed at significantly higher levels $(P<0.05)$ in the galls compared with the uninfected parts of the root (Fig. 3). In group I, the expression of aquaporin AtPIP2.5 was induced 17-fold in galls relative to the rest of the root. Group II genes included AtAAP1, AtAUX1, AtPIP2.6, At2g41190, AtMRP4, and AtLHT4 (Fig. 3). These genes were expressed at similar levels in galls and uninfected sections of root. Group III comprised genes that were expressed more highly in the surrounding root tissue compared with the galls. One gene was AtANT1, whose expression was significantly altered $(P=0.004)$. This gene was downregulated at all three timepoints according to the array results. Another gene, At1g80510, a close relative of AtANT1, was not significantly different between the two tissue types, but was upregulated at all three timepoints compared with the control in the array study.

Table 1. Overview of genes encoding transport proteins whose expression was significantly altered upon nematode infestation ${ }^{\mathrm{a}}$

\begin{tabular}{|c|c|c|c|c|c|c|c|}
\hline \multirow[b]{2}{*}{ Locus tag } & \multicolumn{3}{|c|}{ Fold change $\left(\log _{2}\right)$} & \multirow[b]{2}{*}{$P$ value $^{b}$} & \multirow[b]{2}{*}{ Pattern $^{c}$} & \multirow[b]{2}{*}{ Name } & \multirow[b]{2}{*}{ Family $^{d}$} \\
\hline & Week 1 & Week 2 & Week 4 & & & & \\
\hline At1g58340 & 0.155 & 0.253 & 1.209 & 0.00099 & UUU & AtDTX48 & MOP \\
\hline At $2 \mathrm{~g} 21050$ & 0.361 & 0.636 & 0.948 & 0.00109 & UUU & AtAUX4/LAX3 & AAAP \\
\hline At5g13580 & 1.065 & 0.580 & 0.067 & 0.00138 & UUU & AtWBC6 & $\mathrm{ABC}$ \\
\hline At5g57110 & 0.677 & 1.345 & 0.788 & 0.00146 & UUU & AtACA8 & P-ATPase \\
\hline At4g39030 & 0.795 & 0.470 & 0.630 & 0.00179 & UUU & AtDTX47 & MOP \\
\hline At5g38030 & 0.772 & 0.780 & 0.025 & 0.00256 & UUU & AtDTX30 & MOP \\
\hline At2g39350 & 0.298 & 0.526 & 0.118 & 0.00305 & UUU & AtWBC1 & $\mathrm{ABC}$ \\
\hline At $2 \mathrm{~g} 38120$ & 0.297 & 0.328 & 0.607 & 0.00339 & UUU & AtAUX1 & AAAP \\
\hline At5g54800 & 0.600 & 0.457 & 0.068 & 0.00695 & UUU & AtGPT1 & DMT \\
\hline At3g45680 & 1.652 & 1.014 & 0.223 & 0.00709 & UUU & PTR & POT \\
\hline At1g64780 & 1.399 & 0.565 & 0.350 & 0.00831 & UUU & AtAMT1;2 & AMT \\
\hline At1g71880 & 0.965 & 0.823 & 0.853 & 0.00831 & UUU & SUC1 & GPH \\
\hline At1g58360 & 0.960 & 0.922 & 0.042 & 0.00834 & UUU & AtAAP1 & AAAP \\
\hline At $2 g 39010$ & 0.538 & 0.770 & 0.094 & 0.01110 & UUU & AtPIP2.6 & MIP \\
\hline At5g44370 & 0.499 & 0.231 & 0.127 & 0.01211 & UUU & Transporter & MFS \\
\hline At3g51860 & 0.628 & 0.698 & -0.164 & 0.00006 & UUD & AtCAX3 & $\mathrm{CaCA}$ \\
\hline At5g12860 & 0.692 & 0.342 & -0.080 & 0.00047 & UUD & AtDiT1 & DASS \\
\hline At2g47800 & 0.501 & 0.689 & -0.048 & 0.00633 & UUD & AtMRP4 & $\mathrm{ABC}$ \\
\hline At1g76670 & 0.255 & 0.196 & -0.041 & 0.00783 & UUD & DMT & DMT \\
\hline At1g72140 & 0.657 & 0.563 & -0.003 & 0.00800 & UUD & PTR & POT \\
\hline At2g36910 & 0.472 & 0.481 & -0.105 & 0.01013 & UUD & AtMDR1 & $\mathrm{ABC}$ \\
\hline At5g 27350 & 0.302 & 0.147 & -0.124 & 0.01256 & UUD & AtSFP1 & MFS \\
\hline At5g64290 & 0.304 & 0.146 & -0.143 & 0.01278 & UUD & AtDiT2.1 & DASS \\
\hline At3g03090 & 0.416 & 0.489 & -0.078 & 0.01421 & UUD & STP & MFS \\
\hline At $2 g 41560$ & 0.497 & 0.217 & -0.209 & 0.01606 & UUD & AtACA4 & P-ATPase \\
\hline At1g20840 & 0.967 & -0.082 & 0.497 & 0.01539 & UDU & STP & MFS \\
\hline At $2 \mathrm{~g} 38290$ & 0.116 & -0.660 & -0.622 & 0.00488 & UDD & AtAMT2;1 & AMT \\
\hline At4g32650 & 0.094 & -0.348 & -1.036 & 0.00592 & UDD & AtAKT4/AtKC1 & VIC \\
\hline At1g60960 & 0.067 & -0.223 & -1.027 & 0.00738 & UDD & AtIRT3 & ZIP \\
\hline At3g12100 & 0.042 & -0.213 & -0.624 & 0.01209 & UDD & AtMTPc2 & $\mathrm{CDF}$ \\
\hline At5g 14940 & -0.426 & -0.422 & -0.711 & 0.00003 & DDD & PTR & POT \\
\hline At1g69850 & -0.415 & -0.589 & -0.485 & 0.00008 & DDD & AtNRT1;2 & POT \\
\hline At3g43790 & -0.325 & -0.243 & -0.439 & 0.00017 & DDD & Transporter & MFS \\
\hline At $2 \mathrm{~g} 29650$ & -0.294 & -0.471 & -0.420 & 0.00037 & DDD & Transporter & MFS \\
\hline At3g17700 & -0.145 & -0.949 & -0.873 & 0.00046 & DDD & AtCNGC20 & VIC \\
\hline At3g60160 & -0.534 & -0.194 & -0.482 & 0.00118 & DDD & AtMRP9 & $\mathrm{ABC}$ \\
\hline At5g46040 & -0.501 & -0.670 & -0.807 & 0.00140 & DDD & PTR & POT \\
\hline At5g13740 & -0.362 & -0.214 & -0.480 & 0.00200 & DDD & Transporter & MFS \\
\hline At5g53550 & -0.243 & -0.515 & -0.168 & 0.00282 & DDD & AtYSL3 & OPT \\
\hline At2g40460 & -0.308 & -0.435 & -0.626 & 0.00285 & DDD & PTR & POT \\
\hline At3g11900 & -0.001 & -0.441 & -0.773 & 0.00411 & DDD & AtANT1 & AAAP \\
\hline At $2 \mathrm{~g} 30080$ & -0.215 & -0.332 & -0.654 & 0.00413 & DDD & AtZIP6 & ZIP \\
\hline At4g31710 & -0.213 & -0.336 & -0.621 & 0.00495 & DDD & AtGLR2.4 & GLR \\
\hline At5g67330 & -0.231 & -0.006 & -0.666 & 0.00606 & DDD & AtNRAMP4 & NRAMP \\
\hline At5g52450 & -0.466 & -0.238 & -0.517 & 0.00650 & DDD & AtDTX16 & MOP \\
\hline At5g64840 & -0.532 & -0.455 & -0.695 & 0.00759 & DDD & $\mathrm{ABC}$ & $\mathrm{ABC}$ \\
\hline At3g51870 & -0.344 & -0.374 & -0.593 & 0.00832 & DDD & $\mathrm{MC}$ & $\mathrm{MC}$ \\
\hline At4g18210 & -0.335 & -0.660 & -0.715 & 0.01252 & DDD & AtPUP7 & DMT \\
\hline At1g59740 & -0.153 & -0.496 & -0.783 & 0.01273 & DDD & PTR & POT \\
\hline At1g47530 & -0.416 & -0.536 & -0.448 & 0.01531 & DDD & AtDTX33 & MOP \\
\hline
\end{tabular}

a Transporter nomenclature is according to the ARAMEMNON database (Schwacke et al. 2003).

b Analysis of variance.

${ }^{c}$ Pattern refers to whether genes were upregulated (U) or downregulated (D) at week 1, 2, or 4 after infestation.

${ }^{\mathrm{d}}$ Family abbreviations taken from Saier (2000). 
The tissue-specific expression pattern of a representative of the group I genes was demonstrated using transgenic plants expressing the uidA gene under control of the AtAAP6 promoter 2 weeks after infestation (Fig. 4). The staining pattern of GUS activity in uninfested plants was consistent with a previous study (Okumoto et al. 2002), where it was localized to the vasculature of leaves and regions of lateral root branching (Fig. $4 \mathrm{C}$ and $\mathrm{D}$, arrow heads). In infested plants, additional, stronger staining, which is consistent with the RT-PCR data, was observed in the galls of infested plants (Fig. 4C and D, arrows). To localize the expression of two group I genes (AtAAP6 and $A t P I P 2.5)$ at higher resolution, thin sections were cut from the knots that had been imbedded in agarose. Analysis of these section showed that AtAAP6 and AtPIP2.5 were expressed throughout the entire knot, including the giant cells (Fig. 4E and F).

\section{DISCUSSION}

Nematode-induced giant cells act as feeding sites and display transfer cell-like features (Offler et al. 2003). Previous studies identified two transporters (AtSUC2 and TobRB7) as being involved in nematode feeding sites (Juergensen et al. 2003; Opperman et al. 1994). Recently, it was shown that AtSUC2 is not expressed in syncytia (Hoth et al. 2005). To provide a global perspective of transporter gene expression during the infestation of Arabidopsis plants with the nematode $M$. incognita, a microarray analysis was completed. We found 50 transporter genes whose expression was significantly affected by nematode infestation. The transporter genes are representative of 19 of approximately 80 transporter gene families in Arabidopsis (Busch and Saier 2002). For the majority of the transporters that were regulated in this study (38/50), this is the first report providing any evidence of a connection to some biological process, such as involvement in nematode feeding sites or response to nematode infestation. The representation of specific families of genes in the list of 50 varied between 6 and $17 \%$. For example, the AtCAX family has six genes on the GeneChip and the expression of one was significantly altered, which represents approximately $17 \%$ of the genes in that family. For two large gene families which we quantified, the percentage of genes expressed in specific family members present on the GeneChip, such as ATP binding cassette transporters

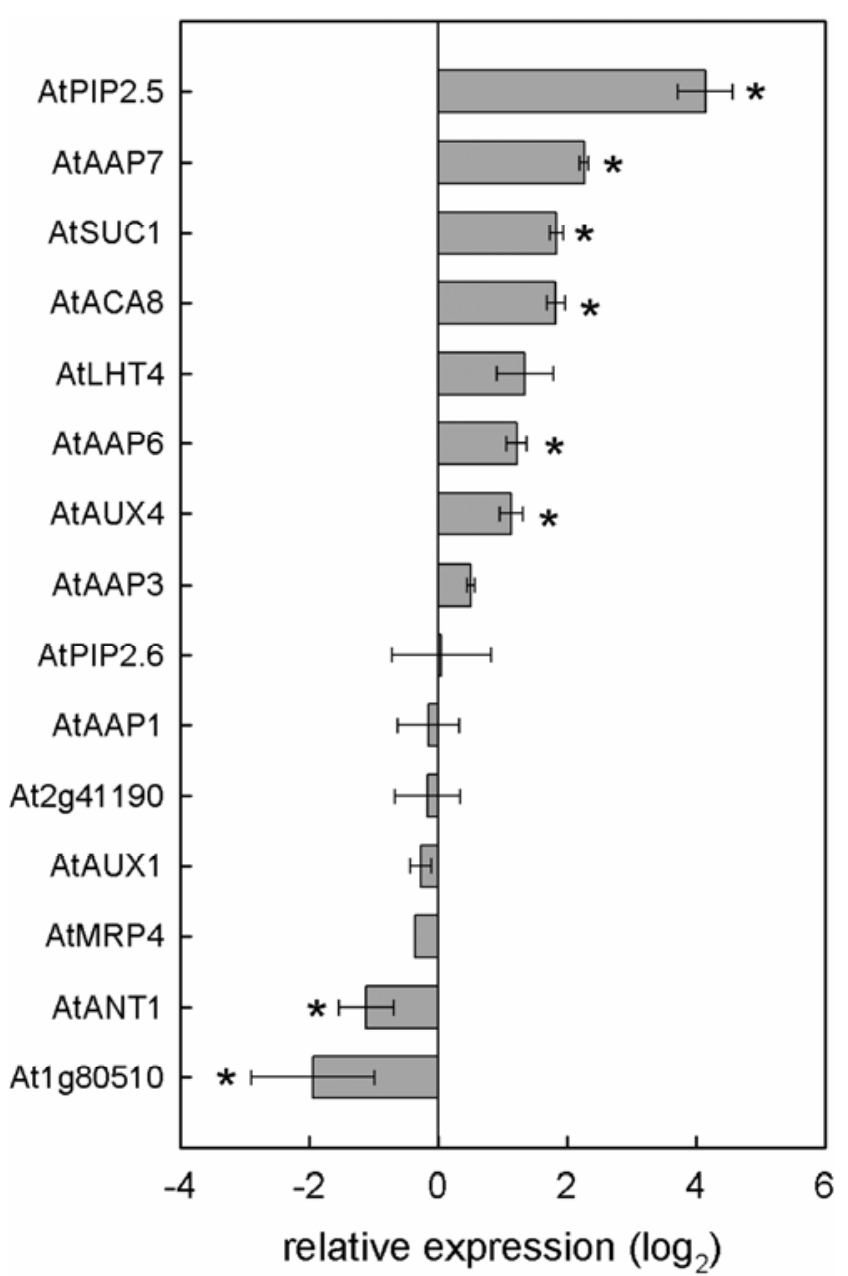

Fig. 3. Expression of 15 genes in knots compared with the rest of the infested roots quantified using real-time reverse-transcriptase polymerase chain reaction. Knots were excised manually from infested roots 2 weeks after infestation. The relative expression levels $\left(\log _{2}\right)$ were calculated in three reps by dividing expression levels in knots with expression levels in the uninfected regions of the roots. Positive values indicate higher expression in the knot and negative values indicate higher expression in the rest of the root. Asterisks indicate a significant difference between expression levels in the knot compared with the rest of the root $(P<0.05)$.
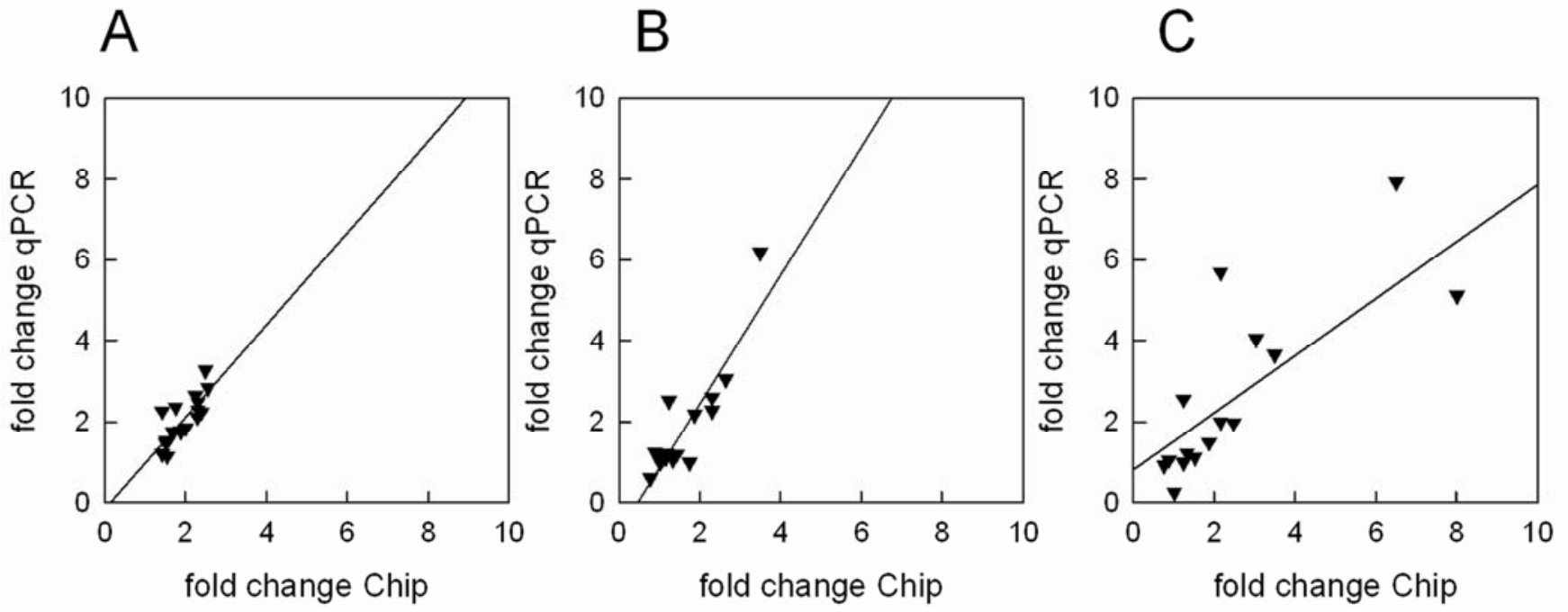

Fig. 2. Correlation between fold changes measured with GeneChip and quantitative real-time reverse-transcriptase polymerase chain reaction (RT-PCR) of 16 genes. The same RNA used to hybridize the arrays was used for real time RT-PCR to determine the reproducibility of the fold changes. Significant correlations between the two methods were obtained in all timepoints. The linear regression line is shown. A, Week $1\left(r^{2}=0.62, P=0.0004\right) ; \mathbf{B}$, week $2\left(r^{2}=\right.$ $0.78, P<0.0001 ;) ; \mathbf{C}$, week $4\left(r^{2}=0.62, P<0.0001\right)$. 
(ABC) (102 family members on GeneChip) and the AAAP family (46 family members on GeneChip), representation was relatively low ( 6 and $9 \%$, respectively). In the case of the peptide transporter family genes (52 family members on GeneChip), representation was relatively high (13\%).

\section{Transporters in symbiosis and pathogenesis.}

Transport processes are known to be important in interactions between plants and other living organisms. In two of the most widespread symbiotic interactions with fungi and bacteria, transporters for phosphate (Harrison et al. 2002; Rausch et al. 2001) and sugars (Flemetakis et al. 2003), channels with conductivities for a number of ions, including ammonium (Tyerman et al. 1995) and aquaporins (Krajinski et al. 2000), have been suggested to play an important role in transfer of minerals and carbon between plants and symbiotic partners. A putative channel-like protein recently was implicated in the ability of nitrogen-fixing bacteria to infect the legume $M$. truncatula (Ane et al. 2004).

In contrast to what is known about the functioning of membrane transport proteins in symbiotic interactions, less is known about the role membrane transport proteins play in plant-parasite interactions. In one case, the disruption of a cyclic nucleotide gated channel has been shown to confer broad-spectrum disease resistance to a bacterial pathogen (Clough et al. 2000). Genes encoding sugar and water transporters have been found to be induced upon wounding and fungal pathogen interaction (Fotopoulos et al. 2003; Meyer et al. 2004; Truernit et al. 1996; Werner et al. 2001). Upon infestation by the nematode $M$. incognita, we found that the expression of 50 transport proteins was significantly different between the nematode-infested roots and the control. This focused analysis of GeneChip data
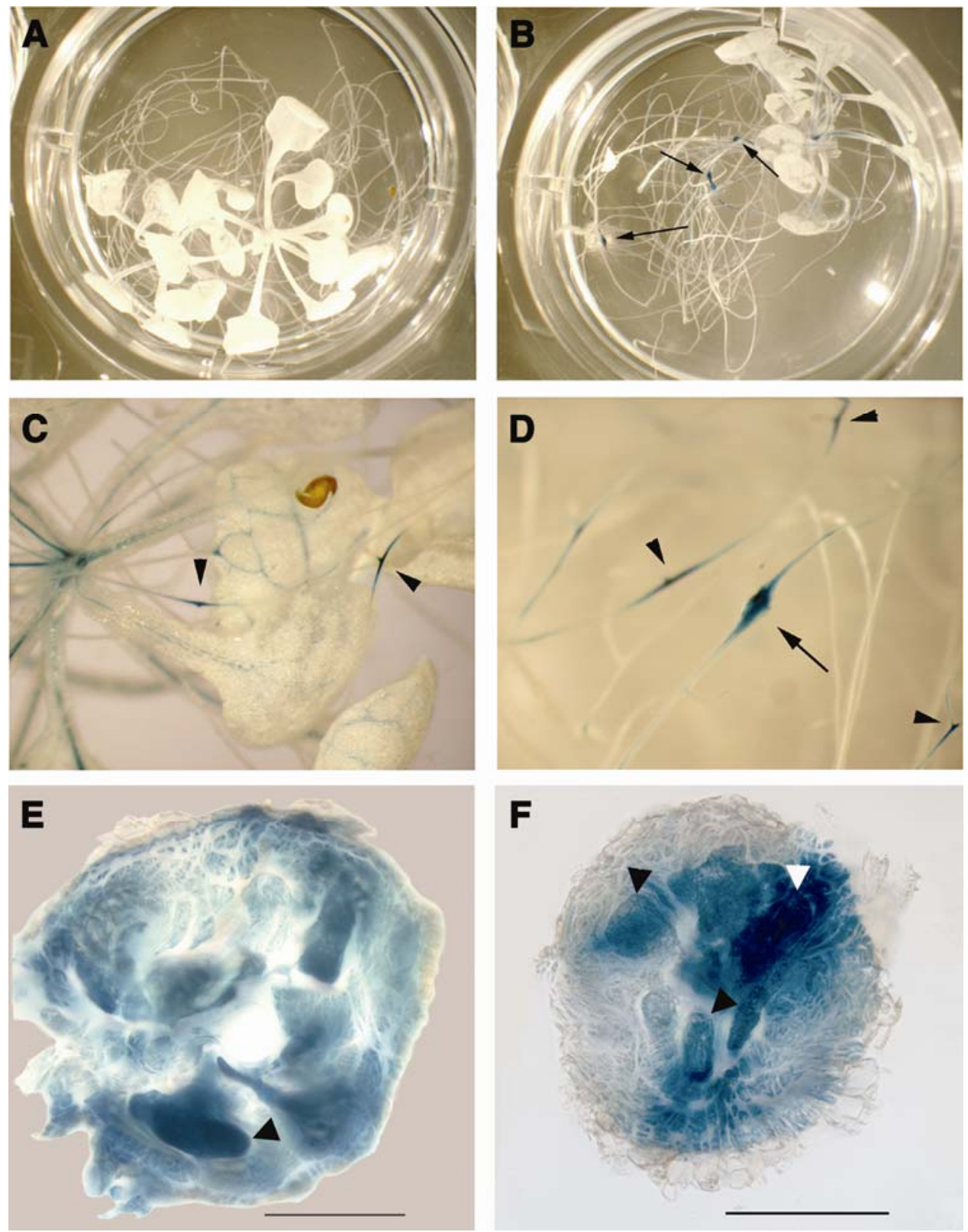

Fig. 4. Expression of the uidA gene under control of the AtAAP6 or AtPIP2.5 promoter. Gene expression in B, D, E, and $\mathbf{F}$, plants 2 weeks after infestation and $\mathbf{A}$ and $\mathbf{B}$, uninfested control plants. The expression level of AtAAP6 is higher in knots (B, arrows) than in the uninfested roots (A). In addition to the knots ( $\mathrm{D}$, arrow), the gene is expressed in the region of root branching (C and D, arrowheads) in both uninfested and infested roots. Thin sections of nematode-infested knots E, AtAAP6 promoter::GUS and F, AtPIP2.5 promoter::GUS. Staining is visible throughout most of the knot, including the giant cells. Arrowheads indicate the location of some of the giant cells. Bars $=100 \mu \mathrm{M}$. 
provides a comprehensive analysis of transporter gene expression in a plant-parasite interaction. We also analyzed the supplemental data from a previous study using the Affymetrix $8 \mathrm{~K}$ GeneChip which focused on the early response to infestation by the beet cyst nematode Heterodera schachtii. From those data, we found that only seven transporter genes were induced (Puthoff et al. 2003). Two of these, AtAAP6 and AtPIP2;5, also were found to be induced by $M$. incognita and, therefore, may be involved in similar processes in the different types of feeding sites. The remaining 48 genes encoding transporters found in our study were not identified in any previous study on nematodes.

\section{Giant-cell development.}

Data from our electron microscopy study in Arabidopsis support findings from root-knot nematode interactions in other plant species (Jones and Payne 1978). In Arabidopsis, we observed many features common to giant cells found in other plant species. Interestingly, two dynamic aspects of giant-cell formation were the observed changes in vacuolar components of the developing giant cell and the development of cell wall ingrowths. When giant cells are initiated, they contain vacuolar structures with size and distribution similar to adjacent nongiant cells. Giant cells at intermediate stages of development prominently display an expanded central vacuole while they maintain smaller vacuolar structures in the peripheral regions of the cell. At present, it is not clear whether these two populations of vacuoles are functionally identical (Bassham and Raikhel 2000; Bethke and Jones 2000). Therefore, the derivation of the large vacuole found in giant cells of intermediate development is currently unknown (Fig. 1B). Still unexplained are the processes that govern the disappearance of this large vacuole as the giant cell matures (Fig. 1C).

Our studies revealed large changes in the ultrastructure of the giant cells over time in Arabidopsis roots, resulting in giant cells with a wall labyrinth, which is the hallmark of a transfer cell (Offler et al. 2003). Transfer cells occur in a variety of tissues at bottlenecks within nutrient transport pathways (Offler et al. 2003). Cell wall proliferation is evident at intermediate stages in giant-cell development (Fig. 1C). However, formation of a cell wall labyrinth occurs only at late stages in development. As the giant cells developed, we also observed many changes in transporter gene expression. In some cases, transporters may play a role in giant-cell development or may transport nutrients into giant cells that are required for nematodes.

\section{Transporters found in developing feeding sites.}

Previous studies of transport processes in transfer-like cells focused on specific transport proteins such as $\mathrm{H}^{+}$-ATPases, sucrose, and amino acid transporters (Offler et al. 2003). The use of the ATH1 GeneChip provided a comprehensive picture of the transport processes induced in Arabidopsis roots during the development of nematode feeding sites. The three timepoints chosen for the GeneChip analysis represent three phases of giant-cell development: initiation, establishment and swelling of giant cells, and maintenance. Because it was not possible to synchronize nematode infestation at the start of these experiments, samples represent the developmental stage which the majority of cells in the knots had reached at each timepoint.

The earliest timepoint which corresponds to the induction of feeding sites was characterized by the expression of organellespecific transporters and primary active transport systems. This may indicate an elevated energy demand by the root, which is consistent with earlier studies (Gheysen and Fenoll 2002; McClure 1977). Two members of the $\mathrm{Ca}^{2+}$-ATPase (ACA) family were upregulated in nematode-infested roots. AtACA4 has been localized to small vacuolar structures which are abundant at early stages of development (Geisler et al. 2000). AtACA8 has been localized to the plasma membrane (Bonza et al. 2000). The expression of AtACA8 was higher in feeding sites than in the rest of the root, which may be indicative of a more specific role in giant-cell formation, but additional data are needed to test this hypothesis. These two genes and AtCAX3 (Hirschi 2001), a member of the $\mathrm{Ca}^{2+}$ :cation antiporter family, have been suggested to play a role in modulating $\mathrm{Ca}^{2+}$-mediated signaling events (Sanders et al. 1999). Based on these data, we suggest that $\mathrm{Ca}^{2+}$ influx and signaling play a role in plant response to nematode infestation and possibly giant-cell or transfer-cell induction and establishment.

At the intermediate timepoint, 2 weeks after infestation, some of the key features of giant-cell development were rapid cell expansion, formation of a large central vacuole, and increased deposition of cell wall material. Changes in expression patterns of some membrane transport proteins in nematodeinfested roots could reflect changes in gene expression in giant cells or in uninfested regions of the root. Therefore, we compared mRNA isolated from dissected root-knots at week 2 with regions of the root that were not infested. We found one aquaporin gene, AtPIP2.6, to be significantly induced in infested roots. According to its expression pattern, this gene appears to be induced throughout infested roots with no significant tissue specificity. In contrast, the expression of its closest relative, AtPIP2.5, which also is induced upon infestation with beet cyst nematode $H$. schachtii (Puthoff et al. 2003), was 17-fold higher in root-knot tissue compared with the rest of the root. The localization of AtPIP2.5 to the root-knot tissue suggests that this gene may be a functional ortholog of a giant-cell-specific aquaporin TobRB7 from tobacco (Opperman et al. 1994; Puthoff et al. 2003). More detailed localization showed that this aquaporin is expressed throughout the gall, including in giant cells.

A sucrose transporter gene, AtSUC1, was significantly induced upon root-knot nematode infestation. The expression of this gene also was higher in feeding sites than in the surrounding tissue (Fig. 3), which is consistent with what is known about the expression of sucrose transporters in seed coat transfer cells (Harrington et al. 1997; Wang et al. 1995). In giant cells, sucrose may be a major osmolyte driving swelling and AtSUC1 may be partly responsible for sucrose transport into the developing giant cells. In contrast, the sucrose transporter gene AtSUC2 was found to be upregulated in syncytia (Juergensen et al. 2003), but does not appear to be directly involved in the active loading of sucrose into syncytia (Hoth et al. 2005). The expression of this transporter gene was unaltered in our experiments. The expression of different sucrose transporters in cyst and rootknot nematode-infested Arabidopsis roots provides additional support for the conclusion that syncytia and giant-cell formation follow different developmental programs.

\section{Amino acid transport in feeding sites.}

We observed large changes in the expression of genes involved in amino acid transport. Overall, the changes were a downregulation of peptide transport and an upregulation of amino acid transporters. In contrast, more peptide transporters than amino acid transporters were induced by cyst nematodes (Puthoff et al. 2003). Most of the amino acid transporters that we investigated in detail were expressed at similar levels in knots versus the rest of the root, suggesting a role for these transporters in the increased amino acid transport capacity of infested roots (Fischer et al. 1995; Okumoto et al. 2002). The expression of AtAAP6 was characterized by both real-time PCR and a promoter::GUS assay. Real-time RT-PCR analysis demonstrated that AtAAP6 was expressed to higher levels in 
knots. This finding was supported by an AtAAP6 promoter:: $G U S$ study which showed that the activity of this promoter was much higher in galls compared with the surrounding tissue and was expressed in both giant cells and other cells in the galls. The role that the amino acid transporter AtAAP6 plays in both cysts and root knots is not yet defined.

Two genes that have been grouped into the AAAP superfamily were induced at the late timepoint. Those genes were AtAUX1 and AtAUX4/LAX3 (At 2g2150), which encode putative auxin transporters (Bennett et al. 1996; Parry et al. 2001; Swarup et al. 2001). Auxin is required for formation of syncytia (Goverse et al. 2000), and auxin levels increase in plant roots infested with nematodes (Viglierchio and Yu 1968). Further studies are required to confirm the substrates that the AUX proteins transport and to determine their role in the establishment and maintenance of the nematode feeding sites.

The results from the microarray experiments provide a global overview of the regulation of 634 transporter genes in the Arabidopsis-root-knot nematode interaction. Further work will be needed to determine the role and functional characteristics of the many newly identified genes that encode transporters regulated by nematode infestation.

\section{MATERIALS AND METHODS}

\section{Sample preparation for microscopy.}

M. incognita-infested roots of Arabidopsis thaliana (Col0 ), grown as described below, were the source of tissues for electron microscopy. Root sections containing giant cells were dissected to fit the specimen planchettes for high-pressure freezing; they were packed in an aqueous solution of $150 \mathrm{mM}$ mannitol and frozen in a Bal-Tec high-pressure freezer. Samples were freeze substituted in acetone containing $2 \%$ osmium tetroxide for 3 days at $-85^{\circ} \mathrm{C}, 15 \mathrm{~h}$ at $-60^{\circ} \mathrm{C}$, and $5 \mathrm{~h}$ at $-30^{\circ} \mathrm{C}$. Then, they were warmed gradually to room temperature, rinsed in acetone, and slowly, over a period of 7 days, infiltrated with Epon-Araldite resin. Thin sections were stained in uranyl and lead salts and observed in a Leo 912 transmission electron microscope (TEM); images were collected with a digital camera.

\section{Microarray sample preparation.}

Wild-type Arabidopsis Col-0 seed were sterilized and germinated on agar plates (2\% sucrose, $0.3 \%$ Gamborg's B-5, $0.6 \%$ Gelrite, $\mathrm{pH} 6.1,8 \mathrm{~h}$ of light and $16 \mathrm{~h}$ of darkness, $23^{\circ} \mathrm{C}$ ). After 7 days, five seedlings were transferred onto each of 84 plates and grown vertically for 3 weeks. At 3 weeks after germination, approximately 1,000 root-knot nematode $(M$. incognita) eggs were added to half of the plates. A set of uninfested plates was kept as a control group. Roots from 70 plants (14 plates containing 5 plants each) were pooled and composed one replicate sample. At each timepoint, three replicates were harvested from both infested and noninfested plants at 1,2, and 4 weeks after inoculation. Infested plants had at least 10 galls per root. RNA was extracted using the RNeasy mini-kit protocol (Qiagen, Valencia, CA, U.S.A.) following the manufacturer's instructions. Isolated RNA was converted into cRNA as described by the Affymetrix protocol. Briefly, cDNAs were synthesized from $20 \mu \mathrm{g}$ of the extracted RNA with the SuperScript Choice System (Invitrogen, Carlsbad, U.S.A.). The BioArray HighYield RNA transcript labeling kit (Enzo Biochem, New York) then was used to transcribe and label the cRNA. The cRNA was fragmented to 200 nucleotides or less, heated at $99^{\circ} \mathrm{C}$ for $5 \mathrm{~min}$, and hybridized for $16 \mathrm{~h}$ at $45^{\circ} \mathrm{C}$ to Arabidopsis ATH1 Genome Arrays (Affymetrix Inc., Santa Clara, CA, U.S.A.). The fluorescence was visualized with an Agilent confocal laser scanner.

\section{Microarray analysis.}

Image data was quantified using GeneChip Analysis Suite/Microarray Suite 5.0 (MAS 5.0). Quality control checks were performed according to standard Affymetrix protocols. In addition, we assessed the concordance among replicates using a weighted kappa coefficient (Fleiss 1981). All replicates were found to be of high quality and so we proceeded with the analyses.

The identification of informative features was performed using default settings $(\alpha 1: 0.04 ; \alpha 2: 0.06 ; \delta: 0.015$; scale factor: 1.0; norm factor: 1.0). If all replicates for a particular feature were deemed "absent," that feature was removed from further consideration. We used the AMPL database (Ward 2001) to identify known transporters. There were 850 transporters identified in this database at the time of our search. We used this list to subset the ATH1 chip and we only analyzed features which corresponded to the known transporters. The features identified as transporters $(n=634)$ were analyzed. Transcript levels were normalized to the overall chip median and log transformed. For each feature, which represents the combined expression data from all relevant probe pairs on the chip, the effect of the mutant and the time stimulus were examined in an analysis of variance modeling framework. (Kerr and Churchill 2001a and b; Oleksiak et al. 2002; Singh et al. 2003; Wayne and McIntyre 2002; Wolfinger et al. 2001). The model $Y_{i j k l}=\mu+\psi_{\mathrm{i}}+\omega_{\mathrm{j}}+\psi \omega_{\mathrm{ij}}+\varepsilon_{\mathrm{ijkl}}$ was fit, where $Y$ is the normalized and $\log$ transformed estimate of signal intensity. The parameter $\mu$ was the overall mean intensity for that feature, $\psi$ represents the effect of the condition (nematode versus control), and $\omega$ represents the effect of week $(j=1,2$, or 4$)$. To test the null hypothesis that a particular feature's expression level was not different across conditions, an $F$ test of the effect of condition was conducted for each feature and a $P$ value was calculated. We examined the model for conformation to the assumption of normality of the residuals by testing the null hypothesis so that the residuals for each feature were normally distributed using the Shapiro-Wilkes test. To determine whether a feature was statistically significant for the effect of condition, we used a false discovery rate (FDR) (Benjamini and Hochberg 1995) of 0.20 for each of the two analyses. Type I and type II errors are inversely related, with decreases in false positives (type I) being associated with increases in false negatives (type II); therefore, we chose an FDR of 0.2 in order to minimize the type II errors without disregarding the type I error. When many tests are performed, keeping the proportion of false discoveries relative to all significant results at a low level is a powerful alternative to the traditional approach of avoiding even a single false discovery (family-wise error rate [FWER]). Control of the FWER at $\alpha$, via Bonferroni or sequential Bonferroni procedures (Holm 1979), is a suitable approach only if the penalty of making even one type I error is severe. In many studies, including this one, avoiding any type I error irrespective of its cost in terms of type II errors is not a satisfactory approach. The Benjamini and Hochberg procedure for FDR control provides a sensible solution: it offers an easily interpretable mechanism to control type I errors while simultaneously reducing type II errors. Control of the false discovery rate is becoming widely used in genomic research (Peng et al. 2003; Sabatti et al. 2003; Storey and Tibshirani 2003; Tusher et al. 2001; Veena et al. 2003; Verhoeven et al. 2005; Weller et al. 1998). Microarray analyses were performed using SAS software (SAS Institute, Cary, NC, U.S.A.).

\section{Data access.}

The processed microarray data are presented according to MIAME standards (Brazma et al. 2001). 
RNA isolation and cDNA synthesis for localization studies.

Roots were harvested from plants 2 weeks postinfestation. The week 2 timepoint was chosen for this analysis because this is the first time period at which knots are readily excised from the surrounding tissue. Knots were excised with a scalpel and the remaining tissue was separated. The two samples were frozen immediately in liquid nitrogen and RNA from both tissues was isolated independently using the QIAGEN RNA isolation kit (Qiagen) following the manufacturer's instructions.

RNA was treated with DNaseI (AMBION, Austin, TX, U.S.A.) according to the manufacturer's protocol. cDNA was synthesized using the Eppendorf cMaster cDNA Synthesis Kit (Eppendorf, Westbury, NY, U.S.A.) and Oligo-dT priming following the manufacturer's protocol.

\section{Quantitative PCR.}

Primers flanking a 90- to 320-bp region specific to the last 800 bases of the $3^{\prime}$ region of each gene of interest and two internal standards (UBQ 10 At4g05320 and elF4 At3g60240) were designed using PrimerSelect (DNAstar, Lasergene, Madison, WI, U.S.A.). Real-time PCR was performed by using an iCycler (BioRAD, Hercules, CA, U.S.A.) and $\mathrm{SyBr}$ green I (Molecular Probes, Eugene, OR, U.S.A.) detection. All reactions were carried out in triplicates. The reactions contained $20 \mathrm{nM}$ Fluorescin (BioRAD) as a passive reference dye. PCR was carried out using the heat-activated Hot Master Taq polymerase (Eppendorf) spiked with $1 \mu \mathrm{l}$ of a 1:10,000 dilution of SYBR green I. The amount of targeted messages in each sample was determined by relating the iCycler results for the gene of interest to a standard curve for each individual gene. Expression levels were normalized to both UBQ10 and elF4 to ensure the similarity of relative expression levels.

For the correlation between chip and RT-PCR results, a linear regression model $y=y_{0}+a x$ was fit and examined for goodness of fit using the $r^{2}$ value.

To test whether a gene was expressed in a specific tissue at a higher level, the null hypothesis that a particular gene's expression level was not different in the two tissues, a $t$ test of the effect of condition was conducted for each gene and a $P$ value was calculated. When $P<0.05$, the null hypothesis was rejected.

\section{Cloning of the promoter fragments and staining for GUS activity.}

The AtAAP6 promoter::uidA fusion construct was described previously (Okumoto et al. 2002). The AtPIP2.5 promoter fragment was amplified from Col-0 genomic DNA using the oligonucleotides 5'-GTCTTCTTATTCTTCACCAAACTTAAG-3' and 5'-GAGGAATAAATTAACAGATTATCACAC-3'. The resulting product was cloned in front of the uidA gene as a transcriptional fusion. For histochemical localization of GUS activity, plant material was infiltrated with X-Gluc at $1 \mathrm{mg} / \mathrm{ml}$ in staining buffer (100 mM Na-Phosphate, $\mathrm{pH}$ 7.0, $10 \mathrm{mM}$ EDTA, $10 \mathrm{mM} \mathrm{K}_{4}\left[\mathrm{Fe}_{2}(\mathrm{CN})_{6}\right], 10 \mathrm{mM} \mathrm{K}_{3}\left[\mathrm{Fe}_{2}(\mathrm{CN})_{6}\right], 1 \%$ Triton X-100, and $10 \%$ dimethyl sulfoxide). Staining was performed for $7 \mathrm{~h}$ at $37^{\circ} \mathrm{C}$. After staining was completed, the plants were transferred to $70 \%(\mathrm{vol} / \mathrm{vol})$ ethanol. For thin sections, root material was fixed overnight in 3\% (vol/vol) gluteraldehyde containing 100 $\mathrm{mM}$ Tris, $\mathrm{pH} 7.5$, and $0.03 \%$ Triton-X 100. Roots then were imbedded in 3\% low-melting-point agarose. Specimens were sectioned to $75 \mu \mathrm{m}$ using a Vibratome Series 1500.

\section{ACKNOWLEDGMENTS}

The National Science Foundation (NSF) Major Research Instrumentation Program provided the funds to purchase the Bal-Tec high pressure freezer and Leo TEM (award DBI-0116650) used in this study. The work was supported by NSF grant 0344265 to C. G. Taylor, D. P. Schachtman, and E. Nielsen and United States Department of Agriculture grant N00149419318 (to L. M. McIntyre). U. Hammes is a Deutsche Forschungsgemeinschaft (DFG) Fellow (HA 3468/1-1). We thank R. Collier for excellent technical assistance and L. Bono for help with programming and data management.

\section{LITERATURE CITED}

Ane, J.-M., Kiss, G. B., Riely, B. K., Penmetsa, R. V., Oldroyd, G. E. D., Ayax, C., Levy, J., Debelle, F., Baek, J.-M., Kalo, P., Rosenberg, C., Roe, B. A., Long, S. R., Denarie, J., and Cook, D. R. 2004. Medicago truncatula DMI1 required for bacterial and fungal symbioses in legumes. Science 303:1364-1367.

Bassham, D. C., and Raikhel, N. V. 2000. Unique features of the plant vacuolar sorting machinery. Curr. Opin. Cell Biol. 12:491-495.

Benjamini, Y., and Hochberg, Y. 1995. Controlling the false discovery rate-a practical approach to multiple testing. J. R. Stat. Soc. Ser. BStat. Methodol. 57:289-300.

Bennett, M. J., Marchant, A., Green, H. G., May, S. T., Ward, S. P., Millner, P. A., Walker, A. R., Schulz, B., and Feldmann, K. A. 1996 Arabidopsis AUX1 gene: A permease-like regulator of root gravitropism. Science 273:948-950.

Bethke, P. C., and Jones, R. L. 2000. Vacuoles and prevacuolar compartments. Curr. Opin. Plant Biol. 3:469-475.

Bird, A. F. 1961. The ultrastructure and histochemistry of a nematodeinduced giant cell. J. Biophys. Biochem. Cytol. 11:701-715.

Bird, A. F., and Loveys, B. R. 1975. The incorporation of photosynthates by Meloidogyne javanica. J. Nematol. 7:111-113.

Bird, D. M., and Wilson, M. A. 1994. DNA sequence and expression analysis of root-knot nematode-elicited giant cell transcripts. Mol. Plant-Microbe Interact. 7:419-424.

Böckenhoff, A., Prior, D. A., Grundler, F. M., and Oparka, K. J. 1996. Induction of phloem unloading in Arabidopsis thaliana roots by the parasitic nematode Heterodera schachtii. Plant Physiol. 112:1421-1427.

Bonza, M. C., Morandini, P., Luoni, L., Geisler, M., Palmgren, M. G., and De Michelis M. I. 2000. At-ACA8 encodes a plasma membrane-localized calcium-ATPase of Arabidopsis with a calmodulin-binding domain at the N terminus. Plant Physiol. 123:1495-1506.

Brazma, A., Hingamp, P., Quackenbush, J., Sherlock, G., Spellman, P., Stoeckert, C., Aach, J., Ansorge, W., Ball, C. A., Causton, H. C., Gaasterland, T., Glenisson, P., Holstege, F. C., Kim, I. F., Markowitz, V., Matese, J. C., Parkinson, H., Robinson, A., Sarkans, U., SchulzeKremer, S., Stewart, J., Taylor, R., Vilo, J., and Vingron, M. 2001. Minimum information about a microarray experiment (MIAME)-toward standards for microarray data. Nat. Genet. 29:365-371.

Busch, W., and Saier, M. 2002. The transporter classification (TC) system, 2002. Crit. Rev. Biochem. Mol. Biol. 37:287-337.

Clough, S. J., Fengler, K. A., Yu, I. C., Lippok, B., Smith, R. K., Jr., and Bent, A. F. 2000. The Arabidopsis dnd1 "defense, no death" gene encodes a mutated cyclic nucleotide-gated ion channel. Proc. Natl. Acad. Sci. U.S.A. 97:9323-9328.

Dorhout, R., Gommers, F. J., and Kolloffel, C. 1991. Water transport through tomato roots infected with Meloidogyne incognita. Phytopathology 81:379-385.

Dorhout, R., Gommers, F. J., and Kollöffel, C. 1993. Phloem transport of carboxyfluorescin through tomato roots infected with Meloidogyne incognita. Physiol. Mol. Plant Pathol. 43:1-10.

Fischer, W. N., Kwart, M., Hummel, S., and Frommer, W. B. 1995. Substrate specificity and expression profile of amino acid transporters (AAPs) in Arabidopsis. J. Biol. Chem. 270:16315-16320.

Fleiss, J. L. 1981. Statistical Methods for Rates and Proportions, 2nd ed. John Wiley \& Sons, Inc., New York.

Flemetakis, E., Dimou, M., Cotzur, D., Efrose, R. C., Aivalakis, G., Colebatch, G., Udvardi, M., and Katinakis, P. 2003. A sucrose transporter, LjSUT4, is up-regulated during Lotus japonicus nodule development. J. Exp. Bot. 54:1789-1791.

Fotopoulos, V., Gilbert, M. J., Pittman, J. K., Marvier, A. C., Buchanan, A. J., Sauer, N., Hall, J. L., and Williams, L. E. 2003. The monosaccharide transporter gene, AtSTP4, and the cell-wall Invertase, At $\beta$ fruct1, are induced in Arabidopsis during infection with the fungal biotroph Erysiphe cichoracearum. Plant Physiol. 132:821-829.

Geisler, M., Frangne, N., Gomes, E., Martinoia, E., and Palmgren, M. G. 2000. The ACA4 gene of Arabidopsis encodes a vacuolar membrane calcium pump that improves salt tolerance in yeast. Plant Physiol. 124:1814-1827.

Gheysen, G., and Fenoll, C. 2002. Gene expression in nematode feeding sites. Annu. Rev. Phytopathol. 40:191-219. 
Gommers, F. J., and Dropkin, V. H. 1977. Quantitative histochemistry of nematode-induced transfer cells. Phytopathology 67:869-873.

Goverse, A., Overmars, H., Engelbertink, J., Schots, A., Bakker, J., and Helder, J. 2000. Both induction and morphogenesis of cyst nematode feeding cells are mediated by auxin. Mol. Plant Microbe Interact. 13:1121-1129.

Guerinot, M. L. 2000. The ZIP family of metal transporters. Biochim. Biophys. Acta 1465:190-198.

Harrington, G. N., Franceschi, V. R., Offler, C. E., Patrick, J. W., Tegeder, M., Frommer, W. B., Harper, J. F., and Hitz, W. D. 1997. Cell specific expression of three genes involved in plasma membrane sucrose transport in developing Vicia faba seed. Protoplasma 197:160-173.

Harrison, M. J., Dewbre, G. R., and Liu, J. 2002. A phosphate transporter from Medicago truncatula involved in the acquisition of phosphate released by arbuscular mycorrhizal fungi. Plant Cell 14:2413-2429.

Hirschi, K. 2001. Vacuolar $\mathrm{H}^{+} / \mathrm{Ca}^{2+}$ transport: Who's directing the traffic? Trends Plant Sci. 6:100-104.

Holm, S. 1979. A simple sequentially rejective multiple test procedure. Scand. J. Stat. 6:65-70

Hoth, S., Schneidereit, A., Lauterbach, C., Scholz-Starke, J., and Sauer, N. 2005. Nematode infection triggers the de novo formation of unloading phloem that allows macromolecular trafficking of green fluorescent protein into syncytia. Plant Physiol. 138:383-392.

Huang, C. S., and Maggenti, A. R. 1969. Wall modifications in developing giant cells of Vicia faba and Cucumis sativus induced by root-knot nematode, Meloidogyne javanica. Phytopathology 59:447-455.

Hussey, R. S. 1989. Disease-inducing secretions of plant-parasitic nematodes. Annu. Rev. Phytopathol. 27:123-141.

Hussey, R. S., and Mims, C. W. 1991. Ultrastructure of feeding tubes formed in giant-cells induced in plants by the root-knot nematode Meloidogyne incognita. Protoplasma 162:99-107.

Hvorup, R. N., Winnen, B., Chang, A. B., Jiang, Y., Zhou, X.-F., and Saier, M. H., Jr. 2003. The multidrug/oligosaccharidyl-lipid/polysaccharide (MOP) exporter superfamily. Eur. J. Biochem. 270:799-813.

Jones, M. G., and Northcote, D. H. 1972. Nematode-induced syncytiuma multinucleate transfer cell. J. Cell Sci. 10:789-809.

Jones, M. G. K. 1980. Host cell responses to endoparasitic nematode attack: Structure and function of giant cells and syncytia. Ann. App. Biol. 97:353-372.

Jones, M. G. K., and Dropkin, V. H. 1976. Scanning electron microscopy of nematode-induced giant transfer cells. Cytobios 15:149-161.

Jones, M. G. K., and Payne, H. L. 1978. Early stages of nematode-induced giant-cell formation in roots of Impatiens balsamina. J. Nematol. 10:70-84.

Juergensen, K., Scholz-Starke, J., Sauer, N., Hess, P., van Bel, A. J. E., and Grundler, F. M. W. 2003. The companion cell-specific Arabidopsis disaccharide carrier AtSUC2 is expressed in nematode-induced syncytia. Plant Physiol. 131:61-69.

Kääb, S., Barth, A. S., Margerie, D., Dugas, M., Gebauer, M., Zwermann, L., Merk, S., Pfeufer, A., Steinmeyer, K., Bleich, M., Kreuzer, E., Steinbeck, G., and Näbauer, M. 2004. Global gene expression in human myocardium-oligonucleotide microarray analysis of regional diversity and transcriptional regulation in heart failure. J. Mol. Med. 82:308-316.

Kerr, M. K., and Churchill, G. A. 2001a. Experimental design for gene expression microarrays. Biostatistics 2:183-201.

Kerr, M. K., and Churchill, G. A. 2001b. Statistical design and the analysis of gene expression microarray data. Genet. Res. 77:123-128.

Krajinski, F., Biela, A., Schubert, D., Gianinazzi-Pearson, V., Kaldenhoff, R., and Franken, P. 2000. Arbuscular mycorrhiza development regulates the mRNA abundance of Mtaqp1 encoding a mercury-insensitive aquaporin of Medicago truncatula. Planta 211:85-90.

Krusberg, L. R., and Nielsen, L. W. 1958. Pathogenesis of root-knot nematodes to the Puerto Rico variety of sweet potato. Phytopathology 48:3039.

Mäser, P., Thomine, S., Schroeder, J. I., Ward, J. M., Hirschi, K., Sze, H., Talke, I. N., Amtmann, A., Maathuis, F. J. M., Sanders, D., Harper, J. F. Tchieu, J., Gribskov, M., Persans, M. W., Salt, D. E., Kim, S. A., and Guerinot, M. L. 2001. Phylogenetic relationships within cation transporter families of Arabidopsis. Plant Physiol. 126:1646-1667.

McClure, M. A. 1977. Meloidogyne incognita: A metabolic sink. J. Nematol. 9:88-90.

Meyer, S., Lauterbach, C., Niedermeier, M., Barth, I., Sjolund, R. D., and Sauer, N. 2004. Wounding enhances expression of AtSUC3, a sucrose transporter from Arabidopsis sieve elements and sink tissues. Plant Physiol. 134:684-693.

Offler, C. E., McCurdy, D. W., Patrick, J. W., and Talbot, M. J. 2003. Transfer cells: Cells specialized for a special purpose. Annu. Rev. Plant Biol. 54:431-454.

Okumoto, S., Schmidt, R., Tegeder, M., Fischer, W. N., Rentsch, D.,
Frommer, W. B., and Koch, W. 2002. High affinity amino acid transporters specifically expressed in xylem parenchyma and developing seeds of Arabidopsis. J. Biol. Chem. 277:45338-45346.

Oleksiak, M. F., Churchill, G. A., and Crawford, D. L. 2002. Variation in gene expression within and among natural populations. Nat. Genet. 32:261-266.

Opperman, C. H., Taylor, C. G., and Conkling, M. A. 1994. Root-knot nematode-directed expression of a plant root-specific gene. Science 263:221-223.

Parry, G., Marchant, A., May, S., Swarup, R., Swarup, K., James, N., Graham, N., Allen, T., Martucci, T., Yemm, A., Napier, R., Manning, K., King, G., and Bennett, M. 2001. Quick on the uptake: Characterization of a family of plant auxin influx carriers. J. Plant Growth Regul. 20:217-225.

Paul, A.-L., Schuerger, A. C., Popp, M. P., Richards, J. T., Manak, M. S. and Ferl, R. J. 2004. Hypobaric biology: Arabidopsis gene expression at low atmospheric pressure. Plant Physiol. 134:215-223.

Peng, J., Ronin, Y., Fahima, T., Roder, M. S., Li, Y., Nevo, E., and Korol, A. 2003. Domestication quantitative trait loci in Triticum dicoccoides, the progenitor of wheat. Proc. Natl. Acad. Sci. U.S.A. 100:24892494.

Puthoff, D. P., Nettleton, D., Rodermel, S. R., and Baum T. J. 2003. Arabidopsis gene expression changes during cyst nematode parasitism revealed by statistical analyses of microarray expression profiles. Plant J. 33:911-921.

Rausch, C., Daram, P., Brunner, S., Jansa, J., Laloi, M., Leggewie, G., Amrhein, N., and Bucher, M. 2001. A phosphate transporter expressed in arbuscule-containing cells in potato. Nature 414:462-470.

Sabatti, C., Service, S., and Freimer, N. 2003. False discovery rate in linkage and association genome screens for complex disorders. Genetics 164:829-833.

Saier, M. H., Jr. 2000. A functional-phylogenetic classification system for transmembrane solute transporters. Microbiol. Mol. Biol. Rev. 64:354 411

Sanders, D., Brownlee, C., and Harper, J. F. 1999. Communicating with calcium. Plant Cell 11:691-706.

Sasser, J. N. 1980. Root-knot nematodes: A global menace to crop production. Plant Dis. 64:36-41.

Schwacke, R., Schneider, A., van der Graaff, E., Fischer, K., Catoni, E., Desimone, M., Frommer, W. B., Flugge, U.-I., and Kunze, R. 2003. ARAMEMNON, a novel database for Arabidopsis integral membrane proteins. Plant Physiol. 131:16-26.

Sijmons, P. C., Grundler, F. M. W., Vonmende, N., Burrows, P. R., and Wyss, U. 1991. Arabidopsis thaliana as a new model host for plantparasitic nematodes. Plant J. 1:245-254.

Singh, A. K., McIntyre, L. M., and Sherman, L. A. 2003. Microarray analysis of the genome-wide response to iron deficiency and iron reconstitution in the cyanobacterium Synechocystis sp. PCC 6803. Plant Physiol. 132:1825-1839.

Sohlenkamp, C., Shelden, M., Howitt, S., and Udvardi, M. 2000. Characterization of Arabidopsis AtAMT2, a novel ammonium transporter in plants. FEBS (Fed. Eur. Biochem. Soc.) Lett. 467:273-278.

Storey, J. D., and Tibshirani, R. 2003. Statistical significance for genomewide studies. Proc. Natl. Acad. Sci. U.S.A. 100:9440-9445.

Swarup, R., Friml, J., Marchant, A., Ljung, K., Sandberg, G., Palme, K., and Bennett, M. 2001. Localization of the auxin permease AUX1 suggests two functionally distinct hormone transport pathways operate in the Arabidopsis root apex. Genes Dev. 15:2648-2653.

Tegeder, M., Offler, C. E., Frommer, W. B., and Patrick, J. W. 2000. Amino acid transporters are localized to transfer cells of developing Pea seeds. Plant Physiol. 122:319-326.

Truernit, E., Schmid, J., Epple, P., Illig, J., and Sauer, N. 1996. The sinkspecific and stress-regulated Arabidopsis STP4 gene: Enhanced expression of a gene encoding a monosaccharide transporter by wounding, elicitors, and pathogen challenge. Plant Cell 8:2169-2182.

Tusher, V. G., Tibshirani, R., and Chu, G. 2001. Significance analysis of microarrays applied to the ionizing radiation response. Proc. Natl. Acad. Sci. U.S.A. 98:5116-5121.

Tyerman, S. D., Whitehead, L. F., and Day, D. A. 1995. A channel-like transporter for $\mathrm{NH}_{4}{ }^{+}$on the symbiotic interface of $\mathrm{N}_{2}$-fixing plants. Nature 378:629-632.

Veena, J. H., Doerge, R. W., and Gelvin, S. B. 2003. Transfer of T-DNA and Vir proteins to plant cells by Agrobacterium tumefaciens induces expression of host genes involved in mediating transformation and suppresses host defense gene expression. Plant J. 35:219-236.

Verhoeven, K., Simonsen, K., and McIntyre, L. M. 2005. Implementing false discovery rate control: Increasing your power. Oikos 108:643-647.

Viglierchio, D. R., and Yu, P. K. 1968. Plant growth substances and plant parasitic nematodes. II. Host influence on auxin content. Exp. Parasitol. 23:88-95 
Wang, R., Okamoto, M., Xing, X., and Crawford, N. M. 2003. Microarray analysis of the nitrate response in Arabidopsis roots and shoots reveals over 1,000 rapidly responding genes and new linkages to glucose, trehalose-6-phosphate, iron, and sulfate metabolism. Plant Physiol. 132:556-567.

Wang, X. D., Harrington, G., Patrick, J. W., Offler, C. E., and Fieuw, S 1995. Cellular pathway of photosynthate transport in costs of developing seed of Vicia faba L. and Phaseolus vulgaris L. II. Principal cellular site(s) of efflux. J. Exp. Bot. 46:49-63.

Ward, J. M. 2001. Identification of novel families of membrane proteins from the model plant Arabidopsis thaliana. Bioinformatics 17:560-563.

Wayne, M. L., and McIntyre, L. M. 2002. Combining mapping and arraying: An approach to candidate gene identification. Proc. Natl. Acad. Sci. U.S.A. 99:14903-14906.

Weller, J. I., Song, J. Z., Heyen, D. W., Lewin, H. A., and Ron, M. 1998. A new approach to the problem of multiple comparisons in the genetic dissection of complex traits. Genetics 150:1699-1706.

Werner, M., Uehlein, N., Proksch, P., and Kaldenhoff R. 2001. Characteri- zation of two tomato aquaporins and expression during the incompatible interaction of tomato with the plant parasite Cuscuta reflexa. Planta 213:550-555

Wolfinger, R. D., Gibson, G., Wolfinger, E. D., Bennett, L., Hamadeh, H., Bushel, P., Afshari, C., and Paules, R. S. 2001. Assessing gene significance from cDNA microarray expression data via mixed models. J. Comput. Biol. 8:625-637.

\section{AUTHOR-RECOMMENDED INTERNET RESOURCES}

Arabidopsis Membrane Protein Library (AMPL) database www.cbs.umn.edu/arabidopsis/index $2 . h t m$

Aramemnon plant membrane protein database: aramemnon.botanik.uni-koeln.de

Affymetrix protocol www.affymetrix.com/support/index.html).

MIAME standards: www.mged.org/Workgroups/MIAME/miame.html

TCDB Transport classification database: www.tcdb.org 